\title{
МОВНІ МАРКЕРИ ЯК ХАРАКТЕРИСТИКА КОНФЛІКТНОСТІ Й АНКОНФЛІКТНОСТІ ОСОБИ
}

\author{
Білоконенко Л. А. Мовні маркери як характеристика конфліктності й \\ анконфліктності особи. \\ У статті описано мовні маркери, які характеризують конфліктність і \\ анконфліктність осіб в інтерперсональному спілкування; визначено захисні мовленнєві \\ механізми осіб у конфліктній взаємодії.
}

Ключові слова: конфліктна взаємодія, мовні маркери, конфліктність і анконфліктність особи.

Белоконенко Л.А. Языковые маркеры как характеристика конфликтности и анконфликтности индивидуума.

В статье описаны языковые маркеры, характеризующие конфликтность и анконфликтность индивидуумов в интерперсональном общения, и защитные речевые механизмы в конфликтном взаимодействии.

Ключевые слова: конфликтное взаимодействие, языковые маркеры, конфликтность и анконфликтность индивидуума.

Bilokonenko L. A. Language markers as a characteristic of conflicting and unconflicting state of an individual.

This article describes the linguistic markers that characterize the state of conflicting and unconflicting of individuals during the process of interpersonal communication, its speech and protective mechanisms in the conflict interaction.

Key words: conflict interaction, linguistic markers, conflicting and unconflicting of an individual.

Сьогодні зайве доводити, що наукове дослідження конфліктів має право на існування. Саме поняття «конфлікт» застосовується щодо широкого кола подій, фактів, змін, які відбуваються в навколишньому середовищі. Тому цей феномен дослідниками описується безвідносно певної галузі знань. Але перш за все він проявляться у процесі комунікації, де має свої властивості, якості, роль. Переважного значення у вивченні конфлікту набуває розкриття поняття мовна діяльність в умовах конфлікту і конфліктної інтерперсональної взаємодії (С. Гладкая, О. Даниленко, Н. Муравйова, В. Третьякова та інші).

Конфлікт за своєю суттю має подвійний характер: один і той самий об'єкт викликає в особи одночасно протилежні почуття. Тож цей соціально-психологічний феномен містить як руйнівний, так і творчий потенціали. Однак у суспільстві переважає уявлення про конфлікт як про лише негативне явище, що зумовлює поведінку особи, яка дозволяє відійти від прямого зіткнення або нейтралізувати конфліктні прояви. Такий відхід реалізується в різних стратегіях поведінки. Вибір цих стратегій $є$ показником некомпетентності, адже суперечливі ситуації залишаються невирішеними і конфлікт переходить у хронічну фазу. Ще Аристотель 
наголошував на здатності людини до співпраці, яка закладена в людській природі. Тож анконфліктність особи $є$ людською сутністю i закономірністю, що випливає з самої природи світу. I на особливу увагу заслуговують питання мовної взаємодії різних соціальних верств, класів, малих груп населення. На сьогодні існують загальнотеоретичні дослідження такої взаємодії, але питання інтерперсонального зв'язку залишається відкритим. Надані в науковій літературі рекомендації щодо комунікативної поведінки в конфлікті мають здебільшого психологічний характер і спрямовані на зняття напруги, як-от: сублімація, заміщення, витіснення, регресія, проекція, раціоналізація, реактивне утворення, ідентифікація, фіксація поведінки. Але дослідженням мовленнєвих захисних механізмів і конструктивної мовленнєвої діяльності в конфлікті відведено незначне місце. Отже, мета нашого дослідження: виявити (за допомогою тестування) мовні маркери, які характеризують конфліктність і анконфліктність осіб в інтерперсональному спілкування, а також визначити основні захисні мовленнєві механізми в конфліктній взаємодії.

Конфліктна взаємодія - це природний процес, який реалізується у мовній комунікації. Вона має свої мовні маркери на різних рівнях мови і фіксується в комунікативній діяльності опонентів. Така діяльність породжує певні розумові утворення за допомогою мовних засобів i формується завдяки процесам сприйняття, розуміння й інтерпретації мови. Конфлікт - комунікативний акт, тому його необхідно розглядати з точки зору всіх суб’єктів комунікації. Від того, наскільки продуктивно і конструктивно реалізується комунікативна стратегія, залежить ефективність i результативність комунікації в умовах конфліктної взаємодії. Н. В. Муравйова визначає, що комунікативна стратегія «проявляється в типових моделях комунікативної і, відповідно, мовної поведінки. Успішна комунікативна стратегія виходить 3 тих чи тих комунікативних постулатів, які демонструють умови успішної комунікації» [4, с. 37]. Особа використовує комунікативні постулати, що відповідають певній моделі комунікації. Існують комунікативні моделі, співвідносні з механізмами виникнення, перебігу і завершення конфліктів різних видів. Але ці моделі «не відповідають» ідеальній, визнаній соціумом поведінці. Такий уявний образ «правильних» конфліктних реакцій протистоїть їхнім реальним життєвим проявам. Тож комунікативні конфлікти є результатом протистояння «правильної» і «неправильної» моделей спілкування, тому існує мова конфлікту і мова анконфлікту.

О. Даниленко зазначає: «Мова конфлікту - це певна семіотична система, що володіє властивістю маркувати i передавати рівень конфліктного потенціалу. Мова конфлікту має свої норми, пов’язані 3 нормами і цінностями соціальної системи» [3, с. 91]. Мова анконфлікту це стабільна нормативна система мовних знаків, яка створює погодження в розумінні й інтерпретації інформації незалежно від сукупності умов, за 
яких відбувається комунікація. Вона відповідає «правильній» моделі спілкування. Неправильне розуміння людьми одне одного є основною причиною інтерперсональних конфліктів. Особа не може передати інформацію без суттєвих перекручувань: частина міститься на рівні несвідомого і словами не виражається; частина втрачається через обмеженість словникового запасу; частина інформації приховується; через брак часу багато не висловлюється; зі сказаного більшість не засвоюється через неуважність. Почуте людина не сприймає на віру, а оцінює, робить висновки, які відрізняються від сказаного опонентом.

Як говорить Н. Муравйова, «оскільки матеріалізацією мовної поведінки виступає текст, то за його мовним характеристикам можна робити висновки про дії комунікантів i правила, яким вони підпорядковуються» [4, с. 64]. За мовними знаками можна визначити i рівень конфліктності й анконфліктності особи. Поняття конфліктності в теорії комунікації розуміють «і як відсутність цілеспрямованого впливу на почуття і думки людей, і як зіткнення інтересів, цілей, поглядів учасників спілкування, у результаті чого одна зі сторін діє свідомо й активно перешкоджає іншій» [7, с. 127]. Тому спілкування зазвичай «розвивається в дусі конфронтації, комуніканти різняться в оцінці ситуації і між ними нерідко виникає почуття антипатії» [4, с. 77]. Цьому слугують мовні маркери, «окремі засоби різних рівнів мови, які завдяки своїм мовним значенням здатні вказувати на наявність у свідомості суб’єкта мови певного змісту, який 3 тих чи тих причин не отримав у тексті свого спеціального вербального вираження» [3, с. 23].

Задля досягнення мети дослідження проведено лінгвоконфліктологічне тестування. У тестуванні взяли участь 103 респонденти (студенти I - IV курсів факультету української філології КДПУ віком від 16 до 22 років, стать - жіноча). На першому етапі використано тест «Самооцінка конфліктності». За результатами тесту визначено, що в $42,8 \%$ студентів рівень конфліктності $є$ найнижчим i коливається від 30 до 44 балів (максимум). Ця група респондентів уважає себе тактовними людьми, які уникають конфліктів, прагнуть бути приємними для оточуючих. Група респондентів, у яких рівень конфліктності є середнім і коливається від 15 до 29 балів, становить 57,2\%. Тест визначає, що таких осіб можна назвати конфліктними. Вони вміють відстоювати свою думку, незважаючи на обставини. Особи з найвищим рівнем конфліктності, які шукають привід для суперечок, люблять критикувати і нав'язують свою думку, не визначені.

Другим етапом тестування стало створення студентами фрагментів спонтанної непідготовленої мови у сфері міжособистісної професійної комунікації. Запропоновано 2 сценарії передконфліктних ситуацій i поставлено вимогу продовжити їхній розвиток так, як це уявляється можливим респондентам. Цінність такої діяльності полягає в тому, що 
вона не просто описує перебіг певних реакцій уявних опонентів, але й завдяки використаним мовним маркерам дозволяє підтвердити, рівень конфліктності респондентів, фактично, робить явними існування зв'язків між самооцінкою конфліктності та іi реальним проявом. Зазначені результати порівняли 3 результатами самооцінки конфліктності. Метою другого етапу було визначення захисних мовленнєвих механізмів осіб у конфліктній взаємодії та їхньої необхідності для формування комунікативних технологій конструктивної конфліктної взаємодії.

Як уже зазначалося, конфліктна взаємодія має свої мовні маркери. Якщо тест із самооцінки конфліктності має відображати реальний рівень конфліктності респондентів, то визначений ступінь має реалізуватися у відповідній мові конфлікту, яка й передає іiі конфліктний потенціал. Різноманітність описаних у літературі дій опонентів можна поєднати в кілька загальних груп або типових стратегій поведінки в конфлікті. Стратегії реалізуються в різних тактиках поведінки або тактиках впливу: раціональне переконання - використання фактів i логіки для підтвердження своєї позиції і переконання опонента; тиск - вимоги, накази, погрози; доброзичливе звернення, запобігання - створення в іншої сторони уявлення про те, що іiі позиція, дії викликають інтерес; коаліція прохання про підтримку третьої сторони; укладання угод - взаємний обмін обіцянками; маніпуляція - створення ефекту несподіванки, удавана схвильованість; погрози - деструктивна тактика, використовується при неготовності поступитися.

Виявлені в тестах тактики раціонального переконання, звернення, доброзичливого запобігання, укладання угод часто реалізуються у використанні питальних речень, які допомагають адресату встановити сутність ситуації загалом. Вони супроводжуються різними емоційними значеннями: незадоволення, апеляція до розуму, інколи роздратування, здивування. Іноді адресат за допомогою питання прагне розібратися в тому, що саме від нього вимагають і прояснити не зовсім зрозумілий для нього спонукальний стимул. Тактики реалізуються у $22 \%$ фрагментів, створених респондентами (авторський стиль тут і далі збережено - Л. Б.): «Я обов'язково піду в лікарню, попрошу вибачення. Але я не впевнена, шзо ії стан здоров'я погіршився саме через нашу сварку», "Я не вважаю себе кар' сристкою, а Вашу думку попрошу обгрунтувати», "Я не вважаю себе кар'сристкою, кожен у світі «крутиться», як може», «Я у відчаї, я обов'язково вибачуся», «Я не думала, щчо нама сварка призведе до такого», «Вибачте, але ичього не могло бути», «Що я наробила?», «Мені прикро, щчо так сталося», «Я вибачуся за те, щуо наговорила. Але, можливо, у нього до нашої розмови були проблеми зі здоров'ям?», "Який жах, але я вибачуся!», «Боже, щуо трапилося? Це я винна!», «Я просто прагну здобути вищу посаду. Я маю чесні наміри. Моє ставлення до колег не зміниться» тощо. 
Тактика коаліції може спонукати опонента відмовитися брати участь у реалізації дії і відмежуватися від можливого прийняття рішення самостійно. Можливе апелювання до суспільної думки, пошук групи підтримки. У досліджуваному матеріалі зустрічаються і мовні ситуації, у яких адресат не бажає виконувати дію без участі мовця чи третьої сторони. Він висуває вимогу, щоб і адресант включився в здійснення дії. Ця тактика реалізується у 3,8 \% фрагментів: «Усі мають зрозуміти, щзо я не хотіла, щоб так сталося», «Думайте, як хочете. Інші так не вважають», «Ніколи за собою такого не помічала, але, як говорять, оточуючим видніме», «Давайте розберемося в ситуаиії, адже ми всі иивілізовані люди», «Я думаю, що всі прагнуть досягнути успіхів у кар'єрі». Сумарний відсоток цих тактик (нейтральних і м'яких) - 25,8 \%, а за тестом самооцінки $42,8 \%$. Відмінність результатів становить $17 \%$. Навіть за умови врахування похибки різниця є досить значною.

Маніпулятивна тактика, тиск і погрози в певних ситуаціях можуть змушувати сторони відмовитися виконувати дії, оскільки вони не впевнені у правах, повноваженнях і можливостях мовця. Це спостерігається, коли в мовній ситуації реалізується порушення соціально-статусного рангу комунікантів. Часто здійснення дій пов'язане з певними обставинами, тоді адресат називає причину, з якої він не в змозі здійснити дію. В інших ситуаціях реакція сторони викликана суб'єктивними причинами, адресат або прямо відмовляється зробити щось, посилаючись на своє небажання i суб'єктивні мотиви, або ж наводить формальні підстави для цього. Зустрічаються різного роду емоційні реакції адресата. Вони супроводжуються конфліктним і дратівливим ставленням до самого факту спонукання і до адресанта. Виявлено випадки, коли адресат навмисно не звертає уваги на тиск, реагуючи зовсім не так, як очікує опонент. Тактики передбачають і використання грубої лексики, образ. Ці мовні маркери порушують толерантність у спілкуванні і змушують опонента реагувати негативно. Зазначені тактики реалізуються в 71,9 \% фрагментів: «Нічого подібного, я така ж людина, як $i$ Ви. Ви помиляєтесь щзодо мене», «Можливо, Ви маєте рацію, але мені ие байдуже», «Я знаю, що мене називають кар'єристкою. І шо з того?», «Я співчуваю иій жіниі, але за себе я буду стояти до кіния», «Я хочу досягти в житті своєї мети, мене не иікавить нічия думка», «Можете вважати мене кар'єристкою. Можу $i$ Вас навчити деяким прийомам», «Мабуть, я винна, але ие на краще $i$ Вас не стосується», «Ви впевнені у свойх словах? Доведіть ие!», «Думайте, як хочете, мене Ваша думка не иікавить», «Це моя особиста справа, я не маю перед Вами звітувати», «Я Вас розумію, але більше так нікому не говоріть», «Не розкидайтеся словами! Обтрунтуйте! Я не збираюся перед Вами звітувати», "Я сказала жінці те, на що вона заслуговувала», «Будьте надалі обережніші, коли будете навішувати на людей ярлики. Це може для Вас погано закінчитися». Ці жорсткі тактики відповідають 
взаємодії саме конфліктних осіб. За тестом самооцінки ця група становить $57,2 \%$. Відмінність результатів - 14,7\%. Знову маємо справу зі значною різницею в показниках. Також виявлено розсіяну, або нечітку, групу реакцій - це 2,3\%: утворені респондентами фрагменти включали спонтанний перехід від однієї тактики до іншої, що свідчить про нерішучість, про сумніви в істинності обраної взаємодії з опонентом.

Спостереження за результатами тестування показують, що у своєму бажанні відтермінувати реакцію на конфліктний подразник адресат спочатку з'ясовує окремі факти, деталі виникнення суперечливої ситуації («Боже, щзо трапилося?», «Ви впевнені у своїх словах?», «Як таке могло трапитися?», «Чому Ви так категоричні зі мною?», «Що я зробила?»), для чого використовуються питальні речення. 3'ясувавши подробиці, респонденти визначаються щодо свої подальших дії. Після прийняття рішення адресат подає сигнал про своє позитивне чи негативне рішення щодо конфлікту («Я визнаю, що образила цюю людину», «Я обов'язково виправлю июю ситуацію», "Я не впевнена, що це сталося через мене», «Невже мої дї погані?»). У деяких випадках просто виходить із спілкування («Це моя справа», «Якщчо Вас не влаштовує моя поведінка, то не звертайте на мене увагу», "Я тут зовсім ні до чого», « $A$ Ви спостережливі!». Звичайно, у фрагментах можна констатувати і почуття антипатії до опонента.

Респонденти формували уявні конфліктні ситуації, але життєвий досвід спонукав їх до певних правил створення мови конфлікту. Відтермінування реакції на подразник було результатом розуміння, що у процесі спілкування інформація перекручується, приховується. Тому репліки опонента не були сприйняті на віру, їх оцінювали і робили висновки. Подання сигналу про своє позитивне чи негативне рішення щодо конфлікту супроводжувалося використанням захисних механізмів, що забезпечило респондентам охорону психіки. Виявлено ознаки таких механізмів психологічного захисту: компенсація («Мені шкода! Bu не підкажете, у якій лікарні він знаходиться, я відвідаю його і вибачуся», «На мою думку, бути кар'єристом краще, ніж нічого не робити», «Я не кар'єристка, я люблю свою справу»); уникнення дійсності («Вважаю, що наша вчорашня бесіда не могла мати таких наслідків. Людина могла мати проблеми зі здоров'ям і до розмови зі мною. Причиною нещастя людини є щось інше»; раціоналізація («Ви не праві. Я не така, я не піду заради кар'єри на низькі вчинки», «Я нікому нічого не винна, тому вчиняю так, як хочу», «Якщо я почала більше заробляти, то це не означає, щэо я це роблю нечесним способом», «Я впевнена, що вона винна сама, вона перша почала сварку і дуже бурхливо»); проекція («Це нормально, коли люди ставлять перед собою певну мету».

Отже, респонденти володіли інформацією про моделі конфліктної комунікації, які «не відповідають» ідеальному зразку суспільно визнаної 
поведінки в конфлікті. Абстрактне уявлення про «правильні» реакцій були витіснені життєвим досвідом. Мова конфлікту стала прийнятною для майже $72 \%$ респондентів. Серед них біля $15 \%$ прихованих конфліктних осіб, які самі себе такими не вважають. Мова анконфлікту була обрана лише у $25,8 \%$ випадків. Отже, мова анконфлікту, хоч і відповідас «правильній» моделі спілкування, не визнана прийнятною для двох третин респондентів.

Саме завдяки мовним маркерам у створених штучно конфліктних фрагментах ми визначили реальний стан конфліктності протестованих осіб. Матеріалізацією мовної поведінки респондентів став створений ними текст. За його мовними характеристиками ми зробили висновки про те, на які дії здатні респонденти та яким правилам комунікації підпорядковуються їхні дії. Нині існує необхідність створення i пропагування нових лінгвосоціологічних моделей конфлікту, які враховують особливості інтерперсональної комунікації в різних соціальних групах і ситуаціях.

Необхідність вивчення мови конфлікту давно вже вийшла за рамки психології. Але якщо мова конфлікту має, як виявлено, свої непорушні «норми», пов'язані з нормами і цінностями соціальної системи, то виникає необхідність зрушити цю непохитну стіну в уявленні мовців.

\section{Література}

1. Анцупов А. Я. Конфликтология: [учебник для вузов] / А. Я. Анцупов, А. И. Шипилов. - М.: ЮНИТИ - Дана, 2001. - 591 с.

2. Гришина Н. В. Психология конфликта / Н. В. Гришина. - СПб: ПИТЕР, 2005. $-464 \mathrm{c}$.

3. Даниленко О. А. Язык конфликта как объект лингвосоциологии / Оксана Акимовна Даниленко // Социологические исследования. - 2006. - № 4. - C. 89-98.

4. Муравьева Н. В. Язык конфликта / Н. В. Муравьева. - М.: Термика, 2004. $214 \mathrm{c}$.

5. Николова А. Речевые тактики и языковые маркеры несогласия и конфликтности при побуждении к действию [Електронний ресурс] / А. Николова. - Режим доступу: http://www.russian.slavica.org/article490.html

6. Пилат Н. Проблема конфліктності людських стосунків у ракурсі філософськосоціологічних та психологічних інтерпретацій [Електронний ресурс] / Наталія Пилат. - Режим доступу: http://znc.com.ua/ukr/publ/periodic/shpp/2005/1/p1 19.php.

$\begin{array}{llll}\text { 7. Третьякова } & \text { В. С. Конфликт глазами лингвиста / } & \text { В. С. Третьякова. - }\end{array}$ Юрислингвистика-2: русский язык в его естественном и юридическом бытии. - Барнаул, 2000. - С. 127-140. 